\author{
DISKUSSIONSPAPIERE \\ DER FAKULTÄT FÜR \\ WIRTSCHAFTSWISSENSCHAFTEN \\ UNIVERSITÄT BIELEFELD
}

Nr. 566 / Juni 2007

Depreciation and Impairment: A Tradeoff in a Stewardship Setting

Andreas Scholze und Stefan Wielenberg 


\title{
Depreciation and Impairment: A Tradeoff in a Stewardship Setting*
}

\author{
Stefan Wielenberg ${ }^{\dagger}$ and Andreas Scholze ${ }^{\ddagger}$
}

Version from June 26, 2007

\footnotetext{
* For helpful comments and suggestions, we thank seminar participants at the universities of Fribourg, Vienna, Dresden and Magdeburg, especially Robert F. Göx, Barbara Schöndube, Dirk Simons and Thomas Pfeiffer.

† Prof. Dr. Stefan Wielenberg, Department of Economics, Leibniz-University Hannover. Address: Königsworther Platz, 30167 Hannover, Gemany. E-Mail: wielenberg@ubwp.uni-hannover.de.

‡ Dipl. Kfm. Andreas Scholze, M.A., Department of Economics and Management Science, Bielefeld University.
} 


\title{
Depreciation and Impairment: A Tradeoff in a Stewardship Setting
}

\begin{abstract}
This paper examines the relationship between depreciation and future impairment losses. This relationship exists, since impairment losses can only be recognized if the carrying amount of an asset exceeds a certain recoverable amount that can be defined in different ways. Sufficiently large depreciation charges in the beginning of the asset's useful life make it very unlikely that an impairment acutally occurs in future periods. In the context of a multi-period agency model with ex ante long-term investment, and ex post shortterm effort incentives, we will show that this relationship causes a tradeoff during the useful life of the asset. In order to induce efficient investment decisions, the investment cost has to be allocated over future periods according to a specific depreciation schedule. However, those depreciation charges decrease the likelihood that impairment losses will occur in later periods. Therefore the information content of the performance measure will be decreased as well. We apply our result to impairment tests according to IFRS and US-GAAP, the accounting for goodwill, and accounting rules for similar problems.
\end{abstract}




\section{Introduction}

Allocating the cost of an asset over time via a method of depreciation and the recognition of future impairment losses are closely related for a simple reason: an impairment loss occurs if the carrying amount (cost of aquisition less accumulated depreciation) of an asset exceeds a specific reference value. However, there is no need for an impairment, if a large amount of the original cost has already been allocated, that means the book value of the asset is sufficiently low. This relationship can lead to a tradeoff if (1) depreciation is necessary in order to match an asset's accounting and economic value and (2) impairment is used as a channel to convey information about the asset's performance during its useful life. Condition (1) is typical for the "measurement perspective" on accounting: ex ante determined depreciation helps to approximate economic value. Condition (2) can be seen as representative for the "information content perspective": impairment charges convey information about ex post performance ${ }^{1}$. In this sense, our paper can also be seen as an attempt to work out a link between these two perspectives.

To illustrate our point, we will adopt a framework that is based on earlier work by Roger son (1997) and Reichelstein (1997). Their approach consists of a multi-period version of the principal-agent setting with unobservable effort and investment decisions. In order to achieve efficient investment decisions, the use of residual income as a performance measure is attractive for two reasons, provided that depreciation is calculated according to a specific rule: (1) Residual income is based on financial accounting data, which are easy to obtain. No forecasts about future data are necessary. (2) In order to achieve efficient effort decisions, there is no constraint in determining the optimal incentive scheme, except that wage payments should be monotonically increasing in residual income.

The second point, however, is critical, if residual income serves as the only performance measure in later periods. The application of a specific depreciation rule in order to achieve efficient investment decisions reduces the carrying amount of the asset and, thus, the probability of informative impairment losses. As a consequence, information about the agent's effort choice in later periods may not be available anymore. Our analysis shows a tradeoff between depreciation charges and impairment losses. If there is no

1 See Beaver/Demski (1979) or Christensen/Demski (2003) for a discussion of these two perspectives on accounting. 
depreciation at all and the asset was initially recorded at fair value in the balance sheet, it is likely that an impairment is necessary in some later period. As a result, an impairment loss recognized in a future period can be an informative signal about the agent's effort choice. Obivously, distorted investment incentives are the price for not using any depreciation charges at all. The degree of distortion depends on the specific rule that is used to calculate the impairment loss. The result not only applies to impairment tests or the revaluation of goodwill. It can be extended to similar accounting transactions like the treatment of R \& D expenses, leasing, or long term construction contracts.

Generally, our result suggests that a transaction with long-term consequences, whose success can be influenced by management, should be recognized in the balance sheet with fair value. Ex ante determined accruals like depreciation and amortization are necessary to provide investment incentives. Ex post accruals like impairment or revaluation convey information about managers effort in later periods. Thus, the tradeoff described above has to be taken in mind.

The results of this paper can be compared to several strands of the literature. In particular, a first group of authors examine incentive effects of performance measures on ex ante investment decisions in agency settings. Rogerson (1997) shows that residual income, calculated with a specific allocation rule (relative benefit allocation rule), yields efficient investment incentives. In addition, Reichelstein (1997) demonstrates that residual income is in several respects the only linear performance measure that induces the manager to invest in profitable projects. Besides the optimal allocation of investment costs by using specific depreciation schedules, there exist several other accounting problems with different effects on ex ante decisions. For example, Dutta/Reichelstein (2005) examine the accounting for long-term construction contracts, leases or the proper valution of receivables. $^{2}$ The accounting rules needed for goal congruence differ from international GAAP in many instances. Sometimes, however, they are at least similar in structure and even compatible with conservative accounting. In contrast to our paper, the work cited above does not take into account operating effort decisions by the agent after he has choosen the level of investment. This is justified by the fact that optimal performance measures in that sense typically leave enough scope for a solution of the incentive prob-

\footnotetext{
2 See Mohnen (2005) on the allocation of negative cash flows, Baldenius/Reichelstein (2005) on the accounting
} for inventory, or Mohnen/Bareket (2007) on the integration of capital constraints in the setting. 
lem in later periods. The tradeoff between the information content of the performance measure in later periods on the one hand, and the ex ante choice of a specific accounting rule on the other, is therefore ignored.

A second group of authors include the solution to the effort decision in later periods in their treatment. Dutta/Reichelstein (2002) show in a multi-period LEN model that by presetting a certain cost of capital, the relative benefit scheme in addition with a wage payment that depends linearly on residual income, induces optimal investment and effort incentives, respectively. In contrast to our paper, residual income in Dutta/Reichelstein (2002) is informative about the agent's effort decision in every period, independent of a specific accounting rule, since the effort choice influences both, the period's cash flow and residual income, in exactly the same way. In Wagenhofer (2003), the agent's effort decisions have an immediate influence on that period's cash flow as well. Thus, there is no relationship between the information content of residual income in a particular period, and an ex ante determined depreciation schedule. Dutta/Reichelstein (2003) examine investment and effort decisions, respectively, by using a so-called "leading indicator", i.e. a signal that is optimal both, in short-term and in long-term contracts. In contrast to our approach, the accounting system is not the only source of information in order to evaluate the manager's effort choice. Furthermore, the accounting for the performance measure in a particular period is independent of the agent's effort decision.

Depreciation and impairment are examples for unconditional and conditional conservatism, respectively. Beaver/Ryan (2005) analyze the impact of a combination of these two forms of conservatism on the relationship between earnings and market returns. Without unconditional conservatism the earnings response to market returns is known to be asymmetric (Basu (1997)), because conditional conservatism implies a stronger response to negative returns. However, unconditional conservatism creates "accounting slack" that prevents the application of conditional conservatism. This is exactly the starting point of our paper. Beaver/Ryan (2005) present a model of conditional and unconditional conservatism and show by simulations that accounting slack weakens the asymmetric earnings response to bad and good market returns. Using their terms, our papers deals with the optimum amount of accounting slack in an agency setting.

The rest of the paper is organized as follows: section 2 presents the model. The tradeoff 
between depreciation and impairment is analyzed in section 3. Some implications and extensions to the model are discussed in section 4. Section 5 examines the tradeoff between ex ante and ex post accruals in alternative accounting problems.

\section{The Model}

Similar to Rogerson (1997) and Reichelstein (1997), we consider an owner of the firm (principal) who delegates an investment decision and a managerial effort decision to a manager (agent). To keep matters simple, our world is restricted to three dates and two periods. The following events and decisions take place in each period:

$t=0$ : The manager observes an unverifiable state of nature $\theta$ that affects future cash flows and is unobservable by the principal. Subsequently, the agent chooses how much to invest. The level of investment, $I$, will affect the value of cash flows in subsequent periods.

$t=1$ : The manager observes the cashflow $c_{1}(I, \theta)=\bar{c}(I, \theta)+\epsilon_{1}$, where the component $\bar{c}(I, \theta)$ is independent of time, and $\epsilon_{1}$ is a random variable with $\mathrm{E}\left[\epsilon_{1}\right]=0$. In addition, the agent exerts an unobservable level of effort, $a_{1}$ that does not affect the cash flow in period 1 and causes personal effort costs, denoted with $k(a)$.

The agent's effort decision leads to a noisy signal, $y_{1}$ with $y_{1}=a_{1}+\lambda . \lambda$ is a random shock term with support $(-\infty,+\infty)$, density $f$, distribution $F$ and expectation zero. The manager leaves the firm at the end of period $t=1$.

$t=2$ : Cash flow $c_{2}(I, \theta)=\bar{c}(I, \theta)+y_{1}+\epsilon_{2}$ realizes.

For sake of simplicity, the agent always reports truthfully to the principal, i.e. the accounting system can be used for an efficient payment contract. Truthful reporting is induced by audited financial statements, for example. The auditor can verify the level of investment, $I$, the cash flows $c_{1}$ and $c_{2}$ as well as the signal $y_{1}$.

As a benchmark, we initially determine the first-best solution. The optimal solution consists of investment and effort decisions that maximize the net present value of the project less payment to the agent. The agent receives a fixed payment as a compensation 
for his effort and opportunity costs. The optimal investment decision, conditional on $\theta$, arises from the following maximization problem:

$$
\max _{I} \frac{\mathrm{E}_{\epsilon_{2}, \lambda}\left[\bar{c}(I, \theta)+\epsilon_{2}+a_{1}+\lambda\right]}{(1+r)^{2}}+\frac{\mathrm{E}_{\epsilon_{1}}\left[\bar{c}(I, \theta)+\epsilon_{1}\right]}{1+r}-I .
$$

Assuming a unique interior solution, $I^{*}$ can be characterized by the first order condition

$$
\phi \cdot \frac{\partial \bar{c}\left(\theta, I^{*}\right)}{\partial I}=1
$$

where

$$
\phi \equiv \frac{(1+r)^{2}-1}{(1+r)^{2} \cdot r} .
$$

The optimal level of effort can by computed by the following problem:

$$
\max _{a} \frac{\mathrm{E}_{\epsilon_{2}, \lambda}\left[\bar{c}\left(I^{*}, \theta\right)+\epsilon_{2}+a+\lambda\right]}{(1+r)}-k(a) .
$$

Maximization of (4) with respect to effort $a$ yields (the usual regularity conditions assumed)

$$
\frac{1}{1+r}=k^{\prime}\left(a^{*}\right)
$$

\section{Analysis}

In this section we analyze the implications of different depreciation and impairment regimes on the agent's investment and effort incentives, respectively. As in the related literatur, we will restrict ourselves to linear contracts based on residual income, giving the agent a fixed compensation and an additional share of the performance measure.

\subsection{Optimal Depreciation Schedule}

Firstly, we replicate that ex ante determined depreciciation schedules can induce efficient investment incentives. The performance measure for the agent's compensation in period 1 is calculated as follows: At $t=0$, the investment has been capitalized in the balance sheet with its initial cost, $I$. Income of period 1 is cash flow less depreciation, i.e. residual 
income in period 1 amounts to $R G_{1}=\bar{c}(I, \theta)+\epsilon_{1}-\left(d_{1}+r\right) \cdot I$. Thus, the agent's objective function at time of the investment decision can be denoted by

$$
\max _{I} \mathrm{E}_{\epsilon_{1}}\left[u\left(w \cdot R G_{1}(\theta, I)+W-k(a)\right)\right] .
$$

The (risk averse) agent has a utility function, denoted with $u(\cdot), w$ indicates the proportional, and $W$ the fix compensation to the agent. Taking the partial derivative with respect to $I$ yields the first order condition

$$
\mathrm{E}\left[u^{\prime}(\cdot) \cdot w \cdot \frac{\partial R G_{1}(\cdot)}{\partial I}\right]=w \cdot\left(\frac{\partial \bar{c}(I, \theta)}{\partial I}-\left(d_{1}+r\right)\right) \cdot \mathrm{E}_{\epsilon_{1}}\left[u^{\prime}(\cdot)\right]=0 .
$$

Since $u^{\prime}(\cdot)>0$ and $w>0$, this simplifies to

$$
\bar{c}_{I}=d_{1}+r
$$

using $\bar{c}_{I} \equiv \frac{\partial \bar{c}(I, \theta)}{\partial I}$. Inserting the depreciation charge, calculated according to the "relative benefit depreciation schedule" (see Rogerson (1997) and Reichelstein (1997)),

$$
d_{1}^{R}=\frac{r}{(1+r)^{2}-1}
$$

shows immediately that first-best investment incentives can be achieved.

Since signal $y_{1}$ is not part of residual income in period 1 , incentives for optimal effort $a^{*}$ cannot be induced. This will change, however, if impairment losses enter the accounting system.

\subsection{Optimal Depreciation Schedule and Impairment Losses}

The recognition of an impairment loss is required if an asset's carrying amount exceeds its "recoverable amount". Depending on the accounting system, the specific definition of this recoverable amount can vary. For illustration purposes, we will refer to the accounting principles of the IASB. IAS 36.18 defines the recoverable amount as the higher of an asset's "fair value less costs to sell" (formerly: "net selling price", hereafter short: FVCS) and its "value in use". For instance, if the value in use of an asset is less than its carrying 
amount (but exceeds the FVCS), the carrying amount of the asset has to be reduced to its value in use.

Determining the value in use involves estimation of future (expected) cash flows to be derived from continuing use of the asset. In our model, this yields the following at the end of period 1:

$$
V U_{1}(I, a)=\frac{\mathrm{E}_{\epsilon_{2}}\left[c_{2}(I, \theta)+a+\lambda\right]}{1+r}=\frac{\bar{c}+a+\lambda}{1+r} .
$$

We assume that the investment project has a FVCS of zero (for example equipment that is designed for the specific needs of the firm). Thus, according to IAS 36, an impairment loss occurs, if and only if the book value in periode $1\left(1-d_{1}\right) \cdot I$ is less than $V U_{1}$.

Calculating residual income involves two cases:

$$
R G_{1}=\bar{c}(\cdot)-d_{1} \cdot I+\epsilon_{1}- \begin{cases}r \cdot I \equiv \mathrm{RG}_{1}^{1}, & \text { if } \lambda>\tilde{\lambda} \\ \left(\left(1-d_{1}\right) \cdot I-\frac{\bar{c}(\cdot)+a+\lambda}{1+r}\right)-r \cdot I \equiv \mathrm{RG}_{1}^{2}, & \text { if } \lambda \leq \tilde{\lambda}\end{cases}
$$

Impairment losses have to be recognized for every realization of the random variable $\lambda$ up to the critical value $\tilde{\lambda}$, where

$$
\begin{aligned}
\left(1-d_{1}\right) \cdot I & =\frac{\bar{c}(\cdot)+a+\lambda}{1+r} \\
\Leftrightarrow \quad \tilde{\lambda} & =(1+r)\left(1-d_{1}\right) I-a-\bar{c}(\cdot) .
\end{aligned}
$$

Next, we consider the investment incentives of the agent. His objective function can be written as

$$
\begin{aligned}
& \max _{I} \mathrm{E}_{\epsilon_{1}}\left[\int_{-\infty}^{\tilde{\lambda}(I, \ldots)} u\left(w \cdot R G_{1}^{2}+W-k(a)\right) f(\lambda) \mathrm{d} \lambda\right] \\
&+\mathrm{E}_{\epsilon_{1}}\left[\int_{\tilde{\lambda}(I, \ldots)}^{\infty} u\left(w \cdot R G_{1}^{1}+W-k(a)\right) f(\lambda) \mathrm{d} \lambda\right] .
\end{aligned}
$$

Again, we assume that the optimal level of investment is uniquely characterized by the 
first-order condition. After rearranging we get

$$
\begin{aligned}
\mathrm{E}_{\epsilon_{1}}\left[\int_{-\infty}^{\tilde{\lambda}} \frac{u^{\prime}\left(w \cdot R G_{1}^{2}+W-k(a)\right)}{u^{\prime}\left(w \cdot R G_{1}^{1}+W-k(a)\right)} \cdot f(\lambda) \mathrm{d} \lambda\right] \cdot( & \left.\bar{c}_{I}\left(1+\frac{1}{1+r}\right)-(1+r)\right) \\
& +(1-F(\tilde{\lambda})) \cdot\left(\bar{c}_{I}-d_{1}-r\right)=0 .
\end{aligned}
$$

Observation 1 summarizes the relationship between the depreciation schedule and the agent's investment decision:

Observation 1 First-best investment incentives can be achieved if and only if the relative benefit depreciation schedule $d_{1}^{R}$ is used.

Proof: For $I=I^{*}$, obviously $\bar{c}_{I}\left(1+\frac{1}{1+r}\right)-(1+r)=0$ is true. If the relative benefit depreciation rule $d_{1}^{R}$ is used, we have $\left(\bar{c}_{I}-d_{1}-r\right)=0$ as well. Thus, the first-order condition is satisfied.

At first glance, it seems surprising that the recognition of an impairment loss does not change the efficiency of the relative benefit depreciation method. This result is caused by using the "value in use" as the recoverable amount. In case of an impairment loss, the marginal effect of a change in $I$ is identical to the partial derivative of the investment's net present value. This specific property disappears, however, if alternative definitions for the recoverable amount will be considered (see section 4.1).

Now we turn to the agent's effort decision. After he has observed the realization of the random variable $\epsilon_{1}$, he chooses his effort level $a$. Thus, he faces the following objective function:

$$
\max _{a} \int_{-\infty}^{\tilde{\lambda}(I, a)} u\left(w \cdot \mathrm{RG}_{1}^{2}+W-k(a)\right) f(\lambda) \mathrm{d} \lambda+\int_{\tilde{\lambda}(I, a)}^{\infty} u\left(w \cdot \mathrm{RG}_{1}^{1}+W-k(a)\right) f(\lambda) \mathrm{d} \lambda .
$$

Taking the partial derivative with respect to $a$ yields the first order condition

$$
\begin{aligned}
\left(\frac{w}{1+r}-k^{\prime}(a)\right) \cdot \int_{-\infty}^{\tilde{\lambda}(I, a)} u^{\prime}(w & \left.\cdot \mathrm{RG}_{1}^{2}+W-k(a)\right) f(\lambda) \mathrm{d} \lambda \\
& -k^{\prime}(a) \cdot \int_{\tilde{\lambda}(I, a)}^{\infty} u^{\prime}\left(w \cdot \mathrm{RG}_{1}^{1}+W-k(a)\right) f(\lambda) \mathrm{d} \lambda=0 .
\end{aligned}
$$


After rearranging we get

$$
\frac{w}{1+r}=k^{\prime}(a) \cdot\left(1+\frac{\int_{\tilde{\lambda}}^{\infty} u^{\prime}(\cdot) f(\lambda) \mathrm{d} \lambda}{\int_{-\infty}^{\tilde{\lambda}} u^{\prime}(\cdot) f(\lambda) \mathrm{d} \lambda}\right) .
$$

Note that the variable compensation $w$ and lowering depreciation charges are substitutes, provided the agent's risk aversion is not too strong. Suppose, the principal wants to induce effort level $\bar{a}$. Then, for a given $\bar{d}_{1}, w$ has to be choosen, such that constraint (16) is satisfied, holding $a$ fixed at $\bar{a}$. Suppose further that the depreciation charge increases to $d_{1}^{\prime}>\bar{d}_{1}$. This leads to an increase of $\tilde{\lambda}$ und therefore (the effect on $u^{\prime}(\cdot)$ neglected) to an increase of the second multiple on the RHS of (16). To maintain equality, $w$ has to be raised.

Thus, we can state:

Observation 2 Provided the agent's risk aversion is not too strong, the following is true: The higher depreciation charge $d_{1}$, the more variable compensation $w$ is necessary in order to implement an action $\bar{a}$.

Proof: The Implicit Function Theorem implies

$$
\frac{\mathrm{d} w}{\mathrm{~d} d_{1}}=-\frac{\frac{\partial \mathrm{FOC}_{a}}{\partial d_{1}}}{\frac{\partial \mathrm{FOC} a}{\partial w}},
$$

where $\mathrm{FOC}_{a}$ is the LHS of the first-oder condition with respect to the agent's effort, defined as $H\left(w, d_{1}\right)=0$. Since $k^{\prime}(a)>0$ and $u^{\prime \prime}(\cdot)<0$, the nominator

$$
-\left.w \cdot I \cdot u^{\prime}\left(w \cdot R G_{1}^{2}+W-k(a)\right)\right|_{\lambda=\tilde{\lambda}} \cdot f(\tilde{\lambda})+k^{\prime}(a) \cdot(1-F(\tilde{\lambda})) \cdot I \cdot u^{\prime \prime}(\cdot)
$$

is negative. The partial derivative in the denominator reads as follows:

$$
\begin{aligned}
\frac{1}{1+r} \cdot \int_{-\infty}^{\tilde{\lambda}} u^{\prime}(\cdot) f(\lambda) \mathrm{d} \lambda+\left(\frac{w}{1+r}-k^{\prime}(a)\right) \cdot \int_{-\infty}^{\tilde{\lambda}} u^{\prime \prime}(\cdot) \cdot \mathrm{RG}_{1}^{2} \cdot f(\lambda) \mathrm{d} \lambda \\
\\
\quad-k^{\prime}(a) \cdot(1-F(\tilde{\lambda})) \cdot u^{\prime \prime}(\cdot) \cdot R G_{1}^{1} .
\end{aligned}
$$

Since $u^{\prime}(\cdot)>0$ and $u^{\prime \prime}(\cdot)<0$, the first and the third term of expression (18) are obvi- 
ously positive. The second term, however, has to be negative because of $\frac{w}{1+r}-k^{\prime}(a)>0$. Hence, for a sufficiently small amount of $u^{\prime \prime}(\cdot)<0$, the denominator will be greater than zero.

It follows immediately from observation 2 that the solution to the agent's operating incentive problem will be more costly for the principal, the higher the depreciation charge in period 1: either $w$ has to be increased as well, or the induced effort level $a$ has to be decreased. The agent has to bear more risk with increasing $w$, which leads to a higher risk premium. A reduction of $a$, however, implies lower cash flows of the project itself.

Without specific assumptions about the distribution of $\lambda$, the utility and cost function, we can only state a very general conclusion about the result of the principal's optimization problem:

Proposition 1 The principal's optimal depreciation charge for period 1, $d_{1}$ has to be choosen from the interval $\left(0, d_{1}^{R}\right)$.

Proof: A depreciation charge $d_{1}>d_{1}^{R}$ is harmful for two reasons: First, underinvestment will be induced and second, the moral-hazard problem will be tightened. So, it is always optimal for the principal to reduce period 1's depreciation charge to $d_{1}^{R}$.

The optimal combination of depreciation and variable compensation to the agent depends on the relative importance of the investment decision on the one hand, the importance of the effort decision, and effort costs, on the other. The more important the investment decision compared to the operating effort choice, the smaller deviations from the relative benefit depreciation schedule will be optimal. If the agent's effort choice gets more relevant, then the principal would rather forgo any depreciation charges in order to increase the likelihood for informative future impairment losses.

\section{Some extensions}

In this section, we examine different aspects of impairment losses in the context of our model, followed by a discussion of the recently reformed revaluation method of goodwill (“impairment-only approach”). 


\subsection{IAS 36 and SFAS 144}

Throughout the last section we used a setting where the value in use was the relevant impairment trigger and impairment basis simultaneously. Now we examine alternative definitions of the recoverable amount. IAS 36.18 defines "recoverable amount as the higher of an asset's [...] fair value less costs to sell [FVCS] and its value in use." The basic idea of this consideration is the fiction of the "optimal" use of an asset. For example, a firm discovers that the service potential of an asset within the company has decreased (value in use is less than carrying amount). This fact does not yet justify an impairment if the net proceeds from a sale of the asset would provide a price higher than the asset's book value (book value less than FVCS). Conversely, suppose the net proceeds from a potential sale of the asset are in fact smaller than it's carrying amount. Then, an impairment can be avoided if sufficiently high cash flows can be expected in the future by using the asset in operations.

From the paper's point of view, it seems interesting to examine variations in the information content of an impairment, depending on the agent's effort level. For illustration purposes, we assume for the moment that the FVCS $V$ does not depend both, on the effort level of the agent, $a$ as well as on the level of investment, $I$. We define $V$ as a random variable that lies within the interval $[\underline{V}, \bar{V}]$, has density $g(V)$ and a distribution function $G(V)$. In addition, $V$ shall be independent of $\lambda$.

In order to calculate period 1's residual income, we now have to consider three cases:

$$
\begin{aligned}
R G_{1}= & \bar{c}(\cdot)+\epsilon_{1}-\left(d_{1}+r\right) \cdot I-\cdots \\
& \cdots- \begin{cases}0 \equiv \mathrm{RG}_{1}^{1}, & \text { if } \lambda>\tilde{\lambda} \text { or } V>\left(1-d_{1}\right) \cdot I \\
\left(\left(1-d_{1}\right) \cdot I-\frac{\bar{c}(\cdot)+a+\lambda}{1+r}\right) \equiv \mathrm{RG}_{1}^{2}, & \text { if } \lambda \leq \tilde{\lambda} \text { and } \lambda>\lambda(V) \\
\left(\left(1-d_{1}\right) \cdot I-V\right) \equiv \mathrm{RG}_{1}^{3}, & \text { if } V<\left(1-d_{1}\right) \cdot I \text { and } \lambda<\lambda(V) .\end{cases}
\end{aligned}
$$

The critical value $\lambda(V) \equiv(1+r) \cdot V-a-\bar{c}(\cdot)$ indicates the realization of the random variable $\lambda$ that leads to identical values of "FVCS" and "value in use". Figure 1 illustrates the situation.

First, we consider the impact of the agent's investment decision. For ease of notation we 


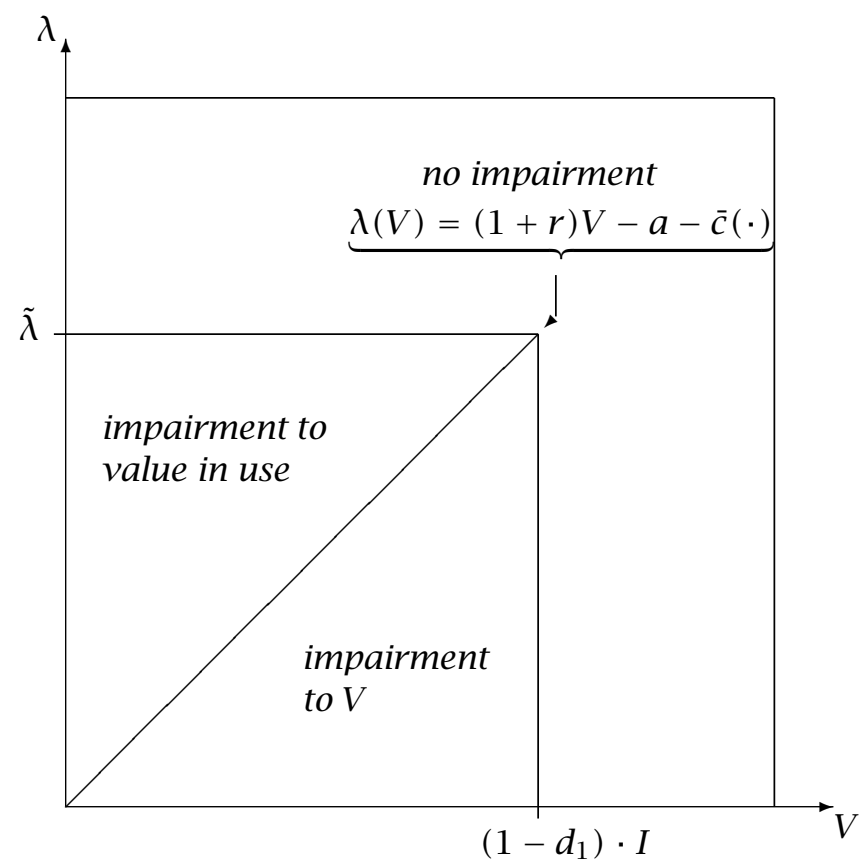

Figure 1: Impairment loss with FVCS

define

$$
u_{i}:=u\left(w \cdot R G_{1}^{i}+W-k(a)\right) .
$$

Using this abbreviation, the agent faces the following maximization problem:

$$
\begin{aligned}
\max _{I} & \mathrm{E}_{\epsilon_{1}}\left[\int_{\underline{V}}^{\left(1-d_{1}\right) I} \int_{-\infty}^{\lambda(V)} u_{3} f(\lambda) g(V) \mathrm{d} \lambda \mathrm{d} V+\int_{\underline{V}}^{\left(1-d_{1}\right) I} \int_{\lambda(V)}^{\tilde{\lambda}} u_{2} f(\lambda) g(V) \mathrm{d} \lambda \mathrm{d} V\right] \\
+\mathrm{E}_{\epsilon_{1}} & {\left[\int_{\underline{V}}^{\left(1-d_{1}\right) I} \int_{\tilde{\lambda}}^{\infty} u_{1} f(\lambda) g(V) \mathrm{d} \lambda \mathrm{d} V+\left(1-G\left(\left(1-d_{1}\right) I\right)\right) u_{1}\right] . }
\end{aligned}
$$

Taking the partial derivative with respect to $I$ yields the first-order condition:

$$
\begin{aligned}
& \left.\mathrm{E}_{\epsilon_{1}}\left[\int_{\underline{V}}^{\left(1-d_{1}\right) I} \int_{-\infty}^{\lambda(V)} u_{3}^{\prime}(\cdot)\right) \cdot\left(\bar{c}_{I}-(1+r)\right) \cdot f(\lambda) g(V) \mathrm{d} \lambda \mathrm{d} V\right] \\
& \left.+\mathrm{E}_{\epsilon_{1}}\left[\int_{\underline{V}}^{\left(1-d_{1}\right) I} \int_{\lambda(V)}^{\tilde{\lambda}} u_{2}^{\prime}(\cdot)\right) \cdot\left(\bar{c}_{I}\left(1+\frac{1}{1+r}\right)-(1+r)\right) \cdot f(\lambda) g(V) \mathrm{d} \lambda \mathrm{d} V\right] \\
& \left.+\mathrm{E}_{\epsilon_{1}}\left[\int_{\underline{V}}^{\left(1-d_{1}\right) I} \int_{-\infty}^{\lambda(V)} u_{1}^{\prime}(\cdot)\right) \cdot\left(\bar{c}_{I}-d_{1}-r\right) \cdot f(\lambda) g(V) \mathrm{d} \lambda \mathrm{d} V\right] \\
& \left.+\mathrm{E}_{\epsilon_{1}}\left[\left(1-G\left(\left(1-d_{1}\right) \cdot I\right)\right) \cdot u_{1}^{\prime}(\cdot)\right) \cdot\left(\bar{c}_{I}-d_{1}-r\right)\right]=0 .
\end{aligned}
$$


Compared to first-order condition (13) and observation 1 we note an important difference: By using the depreciation charge $d_{1}=d_{1}^{R}$, the last three terms in fact disappear (holding $I$ fixed at $I^{*}$ ), but the first term of expression (22) is negative because of $u_{3}^{\prime}(\cdot)>0$ and $\bar{c}_{I}-(1+r)<0$.

Thus, in order to induce $I^{*}$ depreciation charge $d_{1}$ has to be lower than $d_{1}^{R}$. The specific impact of the effect considerably depends on the likelihood that the firm may have to write the asset's carrying amount down to the FVCS. The intuition is as follows: Since the investment decision does not influence the FVCS per assumption, a marginal increase of I increases the impairment charge to period 1's residual income in case of a write-down to the FVCS dollar per dollar. In order to adjust for this negative incentive, the depreciation charge in period 1 has do be reduced. Obviously, this effect will be weakened, if the FVCS depends on the level of investment.

Regarding the manager's effort incentives, we observe two effects. First, the quality of residual income as a signal for the unobservable effort decision of the agent declines: By taking the FVCS under consideration as well, an informative write-down to the value in use will sometimes be prevented. But second, a reduction of the depreciation charge in period 1 leads to a positive second-order effect.

From the managerial effort perspective, only the impairment trigger matters, not the actual level of impairment. The recoverability test in the US-GAAP counterpart to IAS 36, SFAS 144, is an illustrative example. Whenever a certain event or a change in circumstances indicate that the carrying amount of the asset may not recoverable, a so-called "recoverability test" is used to determine whether an impairment has occurred. During the first step, the future net cash flows, expected from the use of that asset, have to be estimated. If the sum of them (undiscounted!) is less than the asset's book value, the asset is considered impaired, otherwise not. Given the the test triggers an impairment, the impairment loss itself is computed as the difference between the carrying amount of the asset and its fair value.

Especially the recoverability test is interesting. According to our model, an impairment loss occurs if $\left(1-d_{1}\right) \cdot I>\bar{c}(\cdot)+a+\lambda$, i.e. for $\lambda<\left(1-d_{1}\right) \cdot I-a-\bar{c}(\cdot)$. Compared to $\tilde{\lambda}$ from expression (11), we note that SFAS 144 is less informative. This, however, is true only if the net selling price is set to zero, like in the first variant of our model. If 
uninformative FVCSs are considered as well, the recoverability test according to SFAS 144 may generate a signal of better quality than the impairment test according to IAS 36.

\subsection{Multi-Period Setting}

Naturally, the negative effects of ex ante determined depreciation schedules will remain if the model is extended to $n$ periods. In fact, the incentive problem will even increase. The more "conservative" the depreciation method, the less likely is the occurrence of impairment losses in future periods. As a result, information that could help to mitigate the moral-hazard problem cannot be conveyed.

In a multi-period setting, the question of reversing an impairment loss becomes apparent. In principle, the reversal of an impairment loss can occur, if there is any indication that an impairment loss recognized in prior periods for an asset may no longer exist. Different accounting systems employ different rules: the obligation to increase the asset's book value to its higher recoverable amount (see, for instance, IAS 36 for assets other than goodwill), the right to choose between reversing the loss or not (see, for instance, § 253 (5) HGB). Sometimes, however, the reversal is prohibited (see, for instance, SFAS 144 or IAS 36 in the case of goodwill).

In our model, we note that reversing an impairment loss has two effects: First, it conveys information about the acutal period of recognition. If the reversal does not depend on the manager's effort choice, this information can be useless, or even harmful for mitigating the moral-hazard problem. Therefore, it is crucial to know first, what event (or action) is responsible for recognizing an reversal and second, what concept lies behind the definition of the recoverable amount. The second effect is strictly positive: reversals of impairment losses generate the potential for informative impairment losses in future periods.

\subsection{Goodwill Impairment}

Besides the application to property, plant and equipment, the revaluation of goodwill serves as another example for the tradeoff between ex ante determined depreciation 
schedules and ex post impairment losses. In 2001, the FASB issued new standards on the accounting for "Business Combinations" (SFAS 141) and for "Goodwill and Other Intangible Assets" (SFAS 142). Besides the fact that pooling-of-interests is not applicable anymore, especially the removal of goodwill amortization has been discussed controversely.

After issuing IFRS 3 "Business Combinations" in 2004 (accompanied by revisions of IAS 36 and IAS 38), similar rules exist for the IFRS. In both accounting systems, periodic depreciation charges for goodwill are displaced by an impairment test (so-called "impairment-only-approach") that may be performed at any time during an annual period.

For example, the procedere, required by IAS 36, can be outlined as follows:

1. Allocating goodwill acquired in a business combination to "cash-generating units". A cash-generating unit is the smallest identifiable group of assets that generates cash inflows that are largely independent of the cash inflows from other assets or groups of assets. The process of allocating goodwill as well as the separation of the firm into distinct cash-generating units leaves considerable scope for managerial discretion (for details see IAS 36.80 ff.).

2. Performing the annual impairment test by comparing the carrying amount of goodwill with its recoverable amount (maximum of value in use and net selling price). If necessary, an impairment loss shall be recognized.

How can the replacement of amortization by an annual impairment test be assessed in the context of our model? Two consequences follow immediately: First, without an ex ante determined amortization schedule, there are incentives for overinvestment if the goodwill's useful life is finite. However, since the depreciation charge becomes very small, if the goodwill can be used for a very long time, this effect becomes less important. On the other hand, if the carrying amount of goodwill is not decreased by periodic depreciation charges, it is more likely to get informative signals about the success of an aquisition in future periods via possible impairment losses. Thus, at first view the new rules for revaluating goodwill look favorably.

However, two problems confine the information content of the impairment-only-approach. 
At first, via the process of allocating goodwill, management can make sure ex ante that impairment losses are less likely ex post. This can be done by separating the firm in only a few, rather large, cash-generating units or by allocating large amounts of goodwill to units that are less risky. Furthermore, internally generated unrecorded goodwill in later periods will help to avoid the impairment of acquired goodwill.

Even though these two problems lower the quality of the goodwill impairment signal, this is no argument in favor of maintaining depreciation charges. In order to assess the impairment-only-approach, it is crucial to know, what events (or actions) may lead to future impairment losses and second, how the amount of the impairment loss may be influenced ex ante by the investment decision. ${ }^{3}$.

\section{Some more accounting problems}

In this section, we show that several other accounting problems exhibit similar tradeoffs in the context of our two-period agency model. Examples are construction contracts, intangible assets, and leasing.

\subsection{Revenue Recognition for Long-Term Construction Contracts}

Two distinctly different methods of accounting for long-term construction contracts are conceivable. For example, the German Commercial Code (HGB) requires the "completedcontract-method", where revenues and gross profit are recognized only when the contract is completed. By contrast, IAS 11 or ARB No. 45 allow to recognize revenues and gross profit during the lifetime of the contract based upon the progress of construction (the so-called "percentage-of-completion-method").

Dutta/Reichelstein (2005) show that in a multi-year model a specific revenue allocation scheme ("present value percentage of completion method") is necessary to create goal

\footnotetext{
3 By means of some examples, Schultze (2005) shows that goodwill impairment according to SFAS 142 can exhibit the character of depreciation charges as well. Furthermore, transitory investment activities or revaluation of other assets, respectively, can also lead to goodwill impairment losses.
} 
congruent investment incentives for the manager. The method allocates the single revenue payment at the end of the contract to the construction period and is thus similar to the relative benefit depreciation schedule.

Does the percentage of completion method also inhibit similar tradeoffs, if we consider the accounting system's ability to convey information about operating effort decisions with respect to the construction contract? An accounting rule without some (however defined) kind of revenue allocation scheme will be inefficient for sure. Without recognizing profits partially over time, the accounting system will only submit information in circumstances where future operating losses are expected. In such a case, international GAAP (like US-GAAP, IFRS or HGB) requires the present obligation to be recognized as a provision or liability. But, for example, the accounting system will never convey information about management's mistakes during the construction term leading to changes in the profitability of a project with expected profits above zero. Therefore, a revenue allocation rule that reacts to modified future prospects of the project (whether positive or negative), is desirable.

As a difference to depreciation and impairment, it is unimportant how total contract revenue is allocated across periods. Each allocation scheme that reacts to changes in the project's conditions conveys information about operating efforts. Thus, the present value percentage of completion method will not restrict the accounting system's informativeness with respect to operating efforts in later periods.

\subsection{Accounting for Internally-Created Intangible Assets}

US - GAAP and IFRS at least partially require the immediate expensing of internally generated intangible assets like R \& D projects. From this paper's perspective, this kind of accounting is harmful in two ways: Neither will investment decisions be efficient (see Dutta/Reichelstein (2005)), nor exists a way to convey the success or failure of a project (possibly influenced of actions taken by the management) via the accounting system. In this respect, the results of our model would suggest to capitalize as much intangibles as possible. Dutta/Reichelstein (2005) show that robust goal congruence in the context of multi-stage investment decisions with abandonment options can be achieved by amor- 
tizing the compounded value of all past cash outlays according to the relative benefit rule. If the manager abandons the project at an intermediate date, it is essential that all past expenditures have to be amortized in exactly the same way that would have resulted if the project had been completed. From our perspective, there is a problem with this approach, because the information about the breakdown of the R \& D project is not reflected in the accounting system. The proposed treatment makes no difference between successful and unsuccessful projects.

\subsection{Accounting for Leases}

There are two common methods of accounting for long-term leases, the operating and the capital method. From the discussion above, it is obvious that capitalization of all long-term leases would be optimal, since only capitalized long-term leases can be amortized over time. Our analysis therefore suggests to favor the capital instead of the operating method (see also Dutta/Reichelstein (2005)). Needless to say that the tradeoff examined above applies to the amortization of the capitalized long-term leases as well.

\section{Concluding Remarks}

Impairment losses have to be recognized if the carrying amount of an asset exceed its recoverable amount - based on market or fair-value considerations. But if a rather conservative depreciation schedule is used, it will be very unlikely that an impairment will occur during the useful life of the asset. In a situation where the manager faces long-term investment decisions ex ante as well as short-term effort decisions ex post, a tradeoff arises. Though depreciation charges are advantageous in order to induce efficient investment decisions, they may prevent informative impairment losses in the future. The precise design of the acconting rules for recognizing impairment losses, considerably influences this tradeoff.

There exist several accounting problems that exhibit similar effects. Altogether, we can state that accounting rules are preferable that exhibit no unconditional conservatism with respect to initial recognition. Unrecognized transactions like leasing, research and 
development, or long term construction contracts induce underinvestment and prohibit informative signals in later periods. Moreover, also initial measurement should not be conservative. A certain amount of unconditional conservatism, however, is helpful in subsequent measurement to induce efficient long term decisions, even though (informative) conditional conservatism becomes less likely.

\section{References}

Baldenius, T. \& Reichelstein, S. (2005), Incentives for Efficient Inventory Management: The Role of Historical Cost. Management Science, 51, 1032 - 1045.

Basu, S. (1997), The Conservatism Principle and the Asymmetric Timeliness of Earnings. Journal of Accounting and Economics, 24, 3 - 37.

Beaver, W. \& Demski, J. (1979), The Nature of Income Measurement. Accounting Review, $54,38-46$.

Beaver, W. \& Ryan, S. (2005), Conditional and Unconditional Conservatism: Concepts and Modeling. Review of Accounting Studies, 10, 269 - 309.

Christensen, J. \& Demski, J. (2003), Accounting Theory - An Information Content Perspective.

Demski, J. \& Sappington, D. (1990), Fully Revealing Income Measurement. The Accounting Review, 65, 363 - 383.

Dutta, S. \& Reichelstein, S. (2002), Controlling Investment Decisions: Depreciation- and Capital Charges. Review of Accounting Studies, 7, 253 - 281.

Dutta, S. \& Reichelstein, S. (2003), Leading Indicator Variables, Performance Measurement, and Long-Term versus Short-Term Contracts. Journal of Accounting Research, 41,837 - 866.

Dutta, S. \& Reichelstein, S. (2005), Accrual Accounting for Performance Evaluation. Review of Accounting Studies, 10, 527 - 552.

Mohnen, A. (2005), Good News für die Steuerung von Investitionsentscheidungen - Eine Verallgemeinerung des relativen Beitragsverfahrens. Zeitschrift für Betriebswirtschaft, 75, $277-297$. 
Mohnen, A. \& Bareket, M. (2007), Performance Measurement for Investment Decisions. Review of Accounting Studies, 12, 1 - 22.

Reichelstein, S. (1997), Investment Decisions and Managerial Performance Evaluation. Review of Accounting Studies, 2, 157 - 180.

Rogerson, W. (1997), Intertemporal Cost Allocation and Managerial Investment Incentives: A Theory Explaining the Use of Economic Value Addes as a Performance Measure. Journal of Political Economy, 105, 770 - 795.

Schultze, W. (2005), The Information Content of Goodwill - Impairment under FAS 142: Implications for External Analysis and Internal Control. Schmalenbach Business Review , 57, 276 - 297.

Wagenhofer, A. (2003), Accrual-based Compensation, Depreciation and Investment Decisions. European Accounting Review, 12, 287 - 309. 
465. Stefan Kardekewitz Analyse der unilateralen Maßnahmen zur Vermeidung der Doppelbesteue-rung im deutschen Erbschaftsteuer-recht Februar 2001

466. Werner Glastetter Zur Kontroverse über das angemessene wirtschafts- und konjunkturpolitische Paradigma -

Einige Akzente der gesamtwirtschaftlichen Entwicklung Westdeutschlands von 1950 bis 1993 März 2001

467. Thomas Braun, Benchmarkorientierte PortfolioAriane Reiss Strategien Mai 2001

468. Martin Feldmann, An incentive scheme for true Stephanie Müller information providing in SUPPLY CHAINS, Juni 2001

469. Wolf-Jürgen Beyn, Dynamic optimization and Skiba sets Thorsten Pampel, in economic examples, Willi Semmler August 2001

470. Werner Glastetter Zur Kontroverse über das angemessene wirtschafts- und konjunkturpolitische Paradigma (II) - Einige Akzente der gesamtwirtschaftlichen Entwicklung der Bundesrepublik Deutschland von 1991-1999, September 2001

471. Hermann Jahnke, Coordinating demand and capacity Anne Chwolka, by adaptive decision making Dirk Simons September 2001

472. Thorsten Pampel Approximation of generalized connecting orbits with asymptotic rate,

September 2001

473. Reinhold Decker Assoziationskoeffizienten und Heiko Assoziationsregeln als Instrumente Schimmelpfennig der Verbundmessung - Eine vergleichende Betrachtung, September 2001

474. Peter Naeve

Virtuelle Tabellensammlung, September 2001

475. Heinz-J. Bontrup Germany's Reform of the Pension Ralf-Michael System: Choice between „Scylla and Marquardt

Charybdis"

Oktober 2001

476. Alexander M. Krüger Wechselkurszielzonen zwischen Euro, Dollar und Yen -- nur eine Illusion? Oktober 2001

477. Jan Wenzelburger Learning to predict rationally when beliefs are heterogeneous. October 2001

478. Jan Wenzelburger

Learning in linear models with expectational leads October 2001

479. Claudia Bornemeyer, Key Success Factors in City Reinhold Decker Marketing - Some Empirical Evidence -

October 2001

488. Reinhold Decker

Fred Becker Michael Tölle

480. Dirk Biskup, Martin Feldmann

481. Dirk Biskup

482. Lars Grüne, Willi Semmler, Malte Sieveking

483. Toichiro Asada

484. Rolf König, Caren Sureth

485. Fred G. Becker, Helge Probst

486. Volker Böhm, Tomoo Kikuchi

487. Caren Sureth

\section{Kai-Stefan Beinke,}

489. $\quad$ Ralf Wagner, Michael Wendling

490. Hans Gersbach, Jan Wenzelburger
Personalentwicklung für Nachwuchswissenschaftler an der Universität Bielefeld: Eine explorative Studie zur Erhebung des IstZustands und zur Begründung von Gestal-tungsvorschlägen Oktober 2001

On scheduling around large restrictive common due windows December 2001

A mixed-integer programming formulation for the ELSP with sequence-dependent setup-costs and setup-times

December 2001

Thresholds in a Credit Market Model with Multiple Equilibria August 2001

Price Flexibility and Instability in a Macrodynamic Model with Debt Effect, February 2002

Die ökonomische Analyse der Auswirkungen der Unternehmenssteuerreform auf Sachinvestitionsentscheidungen vor dem Hintergrund von Vorteilhaftigkeits- und Neutralitätsüberlegungen

- diskreter und stetiger Fall März 2002

Personaleinführung für Universitätsprofessoren: Eine explorative Studie an den Universitäten in NordrheinWestfalen zum Angebot und an der Universität Bielefeld zum Bedarf März 2002

Dynamics of Endogenous Business Cycles and Exchange Rate Volatility April 2002

Die Besteuerun g von Beteiligungsveräußerungen - eine ökonomische Analyse der Interdependenzen von laufender und einmaliger Besteuerung vor dem Hintergrund der Forderung nach Rechtsformneutralität Juli 2002

Data Mining und Datenexploration in der Betriebswirtschaft Juli 2002

Good Odd Prices and Better Odd Prices - An Empirical Investigation September 2002

The Workout of Banking Crises: A Macroeconomic Perspective September 2002 
491. Dirk Biskup, Dirk Simons

Common due date scheduling with autonomous and induced learning September 2002

492. Martin Feldmann, Ralf Wagner

493. Volker Böhm, Jan Wenzelburger

494. J. Frohn, P. Chen, W. Lemke, Th. Archontakis, Th. Domeratzki, C. Flöttmann,

M. Hillebrand,

J. Kitanovic,

R. Rucha, M. Pullen

495. Volker Böhm

\section{CAPM Basics}

December 2002

496. Susanne Kalinowski , Betriebstätte vs. Kapitalgesellschaft Stefan Kardekewitz im Ausland -

eine ökonomische Analyse März 2003

497. Jochen Jungeilges

On Chaotic Consistent Expectations Equilibria

March 2003

498. Volker Böhm MACRODYN

- The Handbook -

March 2003

499. Jochen A. Jungeilges Sequential Computation of Sample Moments and Sample Quantiles - A Tool for MACRODYN April 2003

500. Fred G. Becker, Vera Brenner

Personalfreisetzung in Familienunternehmen:

Eine explorative Studie zur Problematik

Juni 2003

501. Michael J. Fallgatter, "Zum Überwachungsgefüge Dirk Simons.

deutscher Kapitalgesellschaften Eine anreiz-theoretische Analyse der Vergütung, Haftung und Selbstverpflichtung des Aufsichtsrates"

Juni 2003

502. Pu Chen

Weak exogeneity in simultaneous equations models Juli 2003

503. Pu Chen

Testing weak exogeneity in VECM Juli 2003

504. Fred G. Becker, Carmen Schröde

Personalentwicklung von

Nachwuchs-wissenschaftlern: Eine empirische Studie bei Habilitanden des Fachs "Betriebswirtschaftslehre" Juli 2003

505. Caren Sureth
Die Wirkungen gesetzlicher und theo-retischer Übergangsregelungen bei Steuerreformen - eine
506. Jan Wenzelburger

507. Dirk Simons

508. Dirk Simons Dirk Biskup

509. Tomoo Kikuchi

510. Fred G. Becker Oliver Krah

511. Martin Feldmann Stephanie Mülle

512. Xuemin Zhao Reinhold Decker

513. Volker Böhm Jochen Jungeilges

514. Ralf Wagner

515. Ralf Wagner

516. Reinhold Decker Ralf Wagner Sören Scholz

517. Dirk Biskup Martin Feldmann

518. Andreas Scholze

519. Hans Gersbach Jan Wenzelburger

520. Marten Hillebrand Jan Wenzelburger ökonomische Analyse steuerinduzierter Verzerrun-gen am Beispiel der Reform der Besteuerung von Beteiligungserträgen August 2003

Learning to play best response in duopoly games" August 2003

Quasirentenansätze und Lerneffekte September 2003

Besteht ein Bedarf nach Dritthaftung des gesetzlichen Jahresabschlussprüfers?

September 2003

A Note on Symmetry Breaking in a World Economy with an International Financial Market., October 2003

Explorative Studie zur Personaleinführung bei Unternehmen in OWL:

Ergebnisübersicht Oktober 2003

Simulation von Reentrant Lines mit ARENA: Ergebnisse eines Projektes zur Betriebsinformatik Januar 2004

Choice of Foreign Market Entry

Mode

Cognitions from Empirical and

Theoretical Studies

January 2004

Estimating Affine Economic Models

With Discrete Random Perturbations January 2004

Mining Promising Qualification Patterns

February 2004

Contemporary Marketing Practices in Russia

February 2004

Environmental Scanning in

Marketing Planning

- An Internet-Based Approach -

Lot streaming with variable sublots: an integer programming formulation April 2004

Folgebewertung des Geschäfts- oder Firmenswerts aus Sicht der Meßbzw. Informationsgehaltsperspektive April 2004

Do risk premia protect from banking crises?

May 2004

The impact of multiperiod planning horizons on portfolios and asset prices in a dynamic CAPM May 2004 
521. Stefan Wielenberg

522. Sören Scholz, Ralf Wagner
Bedingte Zahlungsversprechen in

der Unternehmenssanierung

Juni 2004

The Quality of Prior Information Structure in Business Planning

- An Experiment in Environmental Scanning -

August 2004

523. Jan Thomas Martini Negotiated Transfer Pricing in a

Claus-Jochen Haake Team-Investment Setting October 2004

524. Reinhold Decker

525. Reinhold Decker Sören Scholz

526. Fred G. Becker Roman Bobrichtchev Natascha Henseler

Market basket analysis by means of a growing neural network

November 2004

Wie viel darf guter Service kosten? Einkaufsstättenbedingte Preiswahrnehmung im Selbstmedikationsmarkt November 2004

Ältere Arbeitnehmer und alternde Belegschaften: Eine empirische

Studie bei den 100 größten deutschen Unternehmen

Dezember 2004

527. Jan Wenzelburger Hans Gersbach

Risk Premia in Banking and the

Macroeconomy"

December 2004

528. Joachim Frohn, Chen Pu

529. Stefan Niermann Joachim Frohn

530. Christoph Wöster

531. Fred G. Becker, Natascha Henseler u.a.

532. Andreas Scholze

533. Marten Hillebrand Jan Wenzelburger

534. Jan Thomas Martini Transfer Pricing for Coordination

535. Klaus Wersching
On the Dynamics of Asset Prices and Portfolios in a Multiperiod CAPM" February 2005 and Profit Determination: An

Analysis

of Alternative Schemes

February 2005

Alternative ökonometrische Zeitverwendungsmodelle

Standortfaktoren und ihre Bedeutung für das Abwandern von

Constructing Arbitrage-free

inomial Models

Fremdmanagement in

Familienunternehmen

Die Bestimmung des Fortführungswerts in der

Unternehmensbewertung mithilfe des Residualgewinnmodells Februar 2005

Innovation and Knowledge Spillover with Geographical and

Technological Distance in an

Agentbased Simulation Model
May 2005

536. Anne Chwolka Jan Thomas Martini Dirk Simons

537. Sören W. Scholz Ralf Wagner

538. Thorsten Pampel

539. Fred G. Becker Michael K. Ruppel

540. Li Xihao Jan Wenzelburger

Accounting-Data-Based Transfer Prices in a Team-Investment Setting May 2005

Autonomous Environmenta Scanning on the World Wide Web June 2005

On the convergence of balanced growth in continous time July 2005

Karrierestau - Ein Problem von Führungskräften wie Organisationen Juli 2005

Auction Prices and Asset Allocations of the Electronic Equity Trading

System Xetra

August 2005

541. Volker Böhm Luca Colombo

Technology Choice with Externalities - A General Equilibrium Approach August 2005

542. Martin Feldmann Dirk Biskup

On lot streaming with multiple products August 2005

543. Christoph Wöster

Die Ermittlung des Conversion Factors im Futures-Handel September 2005

544. Thomas Braun

The impact of taxation on upper and lower bounds of enterprise value October 2005

545. Christoph Wöster

Replication in Consistent Binomial Models

November 2005

546. Thomas Braun

Asymmetrische Information, Beteiligungsfinanzierung und drohende

Überschuldung

Dezember 2005

547. Volker Böhm, Tomoo Kikuchi, George Vachadze

Welfare and the Role of Equity in an Economy with Capital

Accumulation.

December 2005

548. Volker Böhm, Thorsten Pampel, Jan Wenzelburger

On the stability of balanced growth December 2005

549. Jan Wenzelburger Hans Gersbach

Sophistication in Risk Management and Banking Stability:

The Long Term

February 2006

550. Jan Wenzelburger Sophistication in Risk Management and Banking Stability:

The Short Term

February 2006

551. Volker Böhm, Tomoo Kikuchi, George Vachadze

On the Role of Equity for the Dynamics of Capital Accumulation May 2006

552. Andreas Scholze 
Diskussionspapiere der Fakultät für Wirtschaftswissenschaften ab Nr. 465/2001

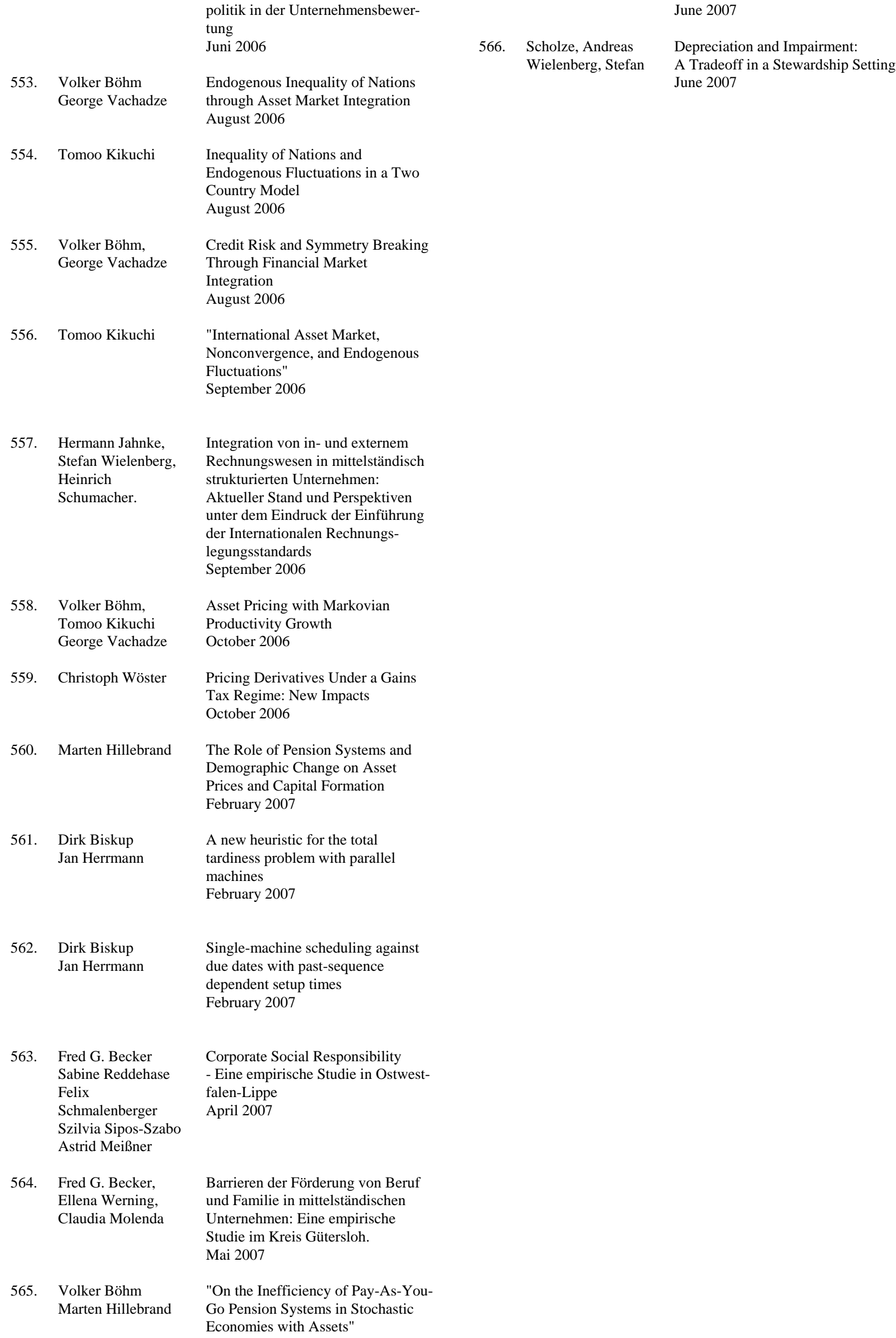

politik in der Unternehmensbewer-

tung

Juni 2006

553. Volker Böhm George Vachadze

Endogenous Inequality of Nations through Asset Market Integration August 2006

554. Tomoo Kikuchi

Inequality of Nations and

Endogenous Fluctuations in a Two

Country Model

August 2006

555. Volker Böhm, George Vachadze

Credit Risk and Symmetry Breaking

Through Financial Market

Integration

August 2006

556. Tomoo Kikuchi

"International Asset Market,

Nonconvergence, and Endogenous

Fluctuations"

September 2006

557. Hermann Jahnke, Stefan Wielenberg,

Heinrich

Schumacher.

Integration von in- und externem

Rechnungswesen in mittelständisch

strukturierten Unternehmen:

Aktueller Stand und Perspektiven

unter dem Eindruck der Einführung der Internationalen Rechnungs-

legungsstandards

September 2006

558. Volker Böhm,

Tomoo Kikuchi

George Vachadze

Asset Pricing with Markovian

Productivity Growth

October 2006

559. Christoph Wöster

Pricing Derivatives Under a Gains

Tax Regime: New Impacts

October 2006

560. Marten Hillebrand

The Role of Pension Systems and

Demographic Change on Asset

Prices and Capital Formation

February 2007

561. Dirk Biskup

Jan Herrmann

A new heuristic for the total

tardiness problem with parallel

machines

February 2007

562. Dirk Biskup

Jan Herrmann

Single-machine scheduling against

due dates with past-sequence

dependent setup times

February 2007

563. Fred G. Becker Sabine Reddehase

Felix

Schmalenberger

Szilvia Sipos-Szabo

Astrid Meißner

564. Fred G. Becker,

Ellena Werning,

Claudia Molenda

565. Volker Böhm Marten Hillebrand

Corporate Social Responsibility

- Eine empirische Studie in Ostwest-

falen-Lippe

April 2007

Barrieren der Förderung von Beruf und Familie in mittelständischen

Unternehmen: Eine empirische

Studie im Kreis Gütersloh.

Mai 2007

"On the Inefficiency of Pay-As-You-

Go Pension Systems in Stochastic

Economies with Assets"

566. Scholze, Andreas Wielenberg, Stefan

June 2007

Depreciation and Impairment:

A Tradeoff in a Stewardship Setting June 2007 